\title{
Pengembangan LKS Trigonometri Berbasis Etnomatematika Pada Masjid Cheng-Ho di Kabupaten Jember
}

\author{
Anas Ma'ruf Annizar ${ }^{*}$, Annisaul Kholida² ${ }^{2}$ Atika Alfitria ${ }^{3}$, Abdullah \\ Subhi Yusuf ${ }^{4}$ \\ 1Tadris Matematika, IAIN Jember, Jember, Indonesia; *anasannizar28@gmail.com \\ 2Tadris Matematika, IAIN Jember, Jember, Indonesia; annisaulkholida20@gmail.com \\ 3Tadris Matematika, IAIN Jember, Jember, Indonesia; alfitriaatika@ gmail.com \\ ${ }^{4}$ Tadris Matematika, IAIN Jember, Jember, Indonesia; asyusuf16100@ gmail.com
}

\begin{abstract}
Abstrak. Penelitian ini bertujuan untuk mengembangkan LKS matematika materi trigonometri berbasis etnomatematikapada masjid Cheng-Ho di Jember. Peneletian ini dilaksanakan untuk mengetahui tingkat kevalidan, kepraktisan, dan keefektivan sebagai pengukur tingkat kualitas LKS. Jenis penelitian yang digunakan adalah Research and Development (R\&D) dan menerapkan penelitian pengembangan model ADDIE. Instrumen yang dipakai dalam mengukur kualitas LKS berupa lembar validasi, angket respon guru dan siswa, serta lembar tes hasil belajar siswa. Dari penelitian ini didapatkan hasil: 1. Kualitas LKS ditinjau dari aspek kevalidan berada pada kategori yang sangat valid, dimana hasilnya termasuk kedalam persentasi yang cukup tinggi yakni validitas materi sebesar 82,5\%, validitas media sebesar $84,4 \%$ dan desain sebesar $81,67 \%$. 2. Kualitas LKS ditinjau dari aspek kepraktisan berada pada kategori tinggi ditunjukkan dari angket guru mencapai presentase 79,63\%, todak hanya itu bahkan persetase yang sangat tinggi juga ditunjukkan berdasarkan pada angket siswa dengan perolehan 89,6\%. 3. Kualitas LKS dilihat dari aspek keefektivan termasuk kedalam kategori efektif, ditunjukkannya dengan dicapainya ketuntas individual dan ketuntasan klasikal dalam tes belajar yang diberikan.
\end{abstract}

Kata Kunci: Etnomatematika, Pengembangan LKS, Trigonometri

\begin{abstract}
This study aims to develop an ethnomatematics-based math worksheets for trigonometric materials at the Cheng-Ho mosque in Jember. This research was conducted to determine the level of validity, practicality, and effectiveness as a measure of the quality level of worksheets. The type of research used is Research and Development (R\&D) and applies the ADDIE model development research. The instruments used in measuring the quality of the worksheets were validation sheets, teacher and student response questionnaires, and student learning outcomes test sheets. From this study, the results obtained: 1 . The quality of the worksheets in terms of validity is in a very valid category, where the results are included in a fairly high
\end{abstract}


percentage of material validity of $82.5 \%$, media validity of $84.4 \%$ and design of 81 , $67 \% .2$. The quality of worksheets in terms of practicality is in the high category shown from the teacher's questionnaire reaching a percentage of $79.63 \%$, not only that, even a very high percentage was also shown based on student questionnaires with an acquisition of $89.6 \%$. 3. The quality of worksheets seen from the aspect of effectiveness is included in the effective category, it is shown by the achievement of individual completeness and classical completeness in the given learning tests.

Keywords: Ethnomatematics, LKS Development, Trigonometry.

\section{Pendahuluan}

Tercapainya suatu tujuan pembelajaran matematika menandakan tercapainya salah satu indikator keberhasilan dari pembelajaran tersebut. Menurut Muafiqi dan Jailani (2014) menyatakan bahwa tujuan pembelajaran berkaitan erat dengan tujuan pendidikan nasional karena selain sebagai hasil penjabaran, tujuan pembelajaran juga termasuk bentuk terperinci dari tujuan pendidikan nasional itu sendiri. Tujuan dari pendidikan nasional yaitu mengembangkan serta meningkatkan potensi setiap siswa sebagai manusia yang beragama, bertaqwa dan beriman kepada Tuhan yang Maha ESA, serta memiliki sifat terampil, beakhlak mulia, berilmu, kreatif, sehat, mandiri dan demokratis sebagai warga negara serta mampu bertanggung jawab. Hal tersebut sesuai dengan yang tercantum pada pasal 3 UU No. 20 tahun 2003 yang membahas mengenai sistem pendidikan nasional.

Tujuan pembelajaran khususnya matematika dapat tercapai apabila guru memperhatikan beberapa komponen pembelajaran seperti materi, strategi, tujuan dan evaluasi pembelajaran. Selain itu, Pengembangan bahan ajar bisa digunakan selaku upaya preventif yang dapat dilakukan guru untuk mencapai keberhasilan pembelajaran. Menurut Nurafni, Pujiastuti dan Mutaqin (2020) menyatakan bahwa semua bahan yang bersifat membantu dan bisa digunakan untuk memperlancar pelaksanaan KBM bagi guru disebut sebagai bahan ajar. Berdasarkan jenisnya, terdapat dua jenis bahan ajar yaitu cetak dan non cetak. Disamping itu, LKS adalah salah satu dari bahan ajar jenis cetak yang bentuknya terdiri dari kumpulan lembaran kertas. Menurut Astuti dan Setiawan (2013) menyatakan bahwa LKS merupakan panduan atau pedoman yang diberikan kepada siswa agar dapat memahami keterampilan serta segala konsep materi yang sedang ataupun yang akan dipelajarinya. Menurut Hasanah, Hafsi dan Zayyadi (2019) menyatakan bahwa penggunaan LKS dapat berperan selaku alat yang dapat memberikan siswa pengetahuan, keterampilan, serta sikap positif. LKS juga dapat membantu pendidik dalam membimbing siswa yang mempunyai kesulitan dalam berpikir, membantu Copyright (C) 2021

Buana Matematika :

Jurnal Ilmiah Matematika dan Pendidikan Matematika 
dalam menanamkan penguatan terhadap materi yang dipelajari serta dapat melatih pola pikir siswa dalam memecahkan suatu masalah.

Memahami konsep matematika merupakan salah satu faktor keberhasilan dari pembelajaran matematika. Siswa yang memiliki pemahaman lebih tinggi mengenai konsep matematika akan lebih mudah mengetahui dan memahami konsep matematika yang masih terselubung atau yang masih tersembunyi (Lestari \& Annizar, 2020; Annizar, dkk., 2018). Pengetahuan yang didapatkan berdasarkan pemahaman konsep akan memberikan dasar pada siswa dalam pembentukan pengetahuan baru serta dapat digunakan untuk memcahkan masalah-masalah selanjutnya (Annizar, dkk., 2020; Aini, dkk.,2020). Dengan pamahan konsep juga, siswa dapat lebih leluasa dalam menyampaikan pendapatnya. Sehingga, siswa tidak perlu lagi menghafalkan rumus untuk memecahkan masalah namun lebih kepada menalar dari konsep yang sudah ada (Maulyda, dkk., 2020; Annizar, dkk., 2020).

Salah satu cara yang bisa dilakukan untuk mempermudah siswa dalam memahami konsep matematika adalah menghubungkan matematika dengan lingkungan/budaya sekitar atau yang biasa disebut etnomatematika. Etnomthematics merupakan matematika berbasis budaya yang diintegrasikan ke dalam kelas matematika. Menurut Hasanah, dkk (2019) menyatakan bahwa etnomatematika juga didefinisikan sebagai ide atau kajian matematika yang berkaitan dengan budaya dan kehidupan sosial yang berlaku dimasyarakat baik kebiasaan, tabiat atau pun adat. Menurut Hasanah, dkk (2019) menyatakan bahwa etnomatematika mempengaruhi perbedaan sikap dan keputusan seseorang yang disebabkan karena perbedaan dalam mengimplementasi matematika dan berujung dalam menciptakan langkahlangkah yang berbeda pula dalam menyelesaikan atau memecahkan permasalahan matematika baik dari cara berhitung, mengelompokkan, merancang alat atau bangunan, permainan, dan lainnya. Dalam etnomatematika juga dapat memuat konsep matematika yang ada pada permainan tradisional (Khairunnisa, dkk., 2020; Annizar, dkk., 2020;).

Dalam penelitian ini, peneliti berusaha membangun kemampuan siswa dalam memahami konsep dengan mengembangkan LKS materi trigonometri berbasis etnomatematika pada masjid Cheng-Ho di Kabupaten Jember sebagai bahan ajar. Peneliti dalam penelitian ini memilih masjid Cheng-Ho untuk diintegrasikan pada LKS, karena masjid Cheng-Ho merupakan masjid yang terkenal di Jember dengan budaya dan keunikannya serta siswa familiar dengan bangunan ini. Beranjak dari hal itu peneliti merasa penting untuk 
membuat LKS yang terintegrasi dengan etnomatematikamasjid Cheng-Ho pada materi trigonometri, agar siswa lebih mudah menangkap materi yang diberikan. Peneliti mengembangkan LKS sebagai bahan ajar yang juga berbasis kearifan lokal yang kemudian diintegrasikan dengan konsep matematika pada materi trigonometri yang dikhususkan pada kelas $X$ MA/SMA/SLTA sederajat. Menurut Rizki dan Ruli (2016) menyatakan bahwa trigonometri termasuk materi pelajaran matematika yang terdapat pada jenjang tingkat SLTA sederajat sampai perguruan tinggi, dimana trigonometri akan diberikan setelah guru memberikan materi tentang phytagoras yang merupakan materi prasyarat.

Dalam penelitian sebelumnya Nurafni, dkk (2020) mengemukakan bahwa pengembangan kearifan lokal yang diimplementasikan kedalam bahan ajar materi trigonometri yang disesuaikan dengan karakteristik siswa dapat meningkatkan pengetahuan siswa terkait ciri khas yang ada di daerahnya yaitu di Banten serta meningkatkan hasil belajar siswa. Sementara dalam penelitian yang dilakukan oleh Oktarina, dkk (2019) mengemukakan bahwa lembar kerja siswa terintegrasi etnomatematika berbasis penemuan terbimbing pada rumah adat Sumatera Selatan yang dikembangkan dinyatakan valid, praktis, dan potensial dalam meningkatkan hasil belajar siswa khususnya pada materi bangun ruang sisi datar. Berbeda dengan dua penelitian sebelumnya, peneliti dalam penelitian ini mengembangkan LKS pada materi trigonometri berbasis etnomatematika pada masjid Cheng-Ho di Jember, dimana penelitian tersebut belum pernah dijumpai oleh peneliti. Oleh sebab itu, peneliti merasa penting untuk mengembangkan produk tersebut.

Berdasarkan paparan-paparan tersebut, keberadaan LKS yang diintegrasikan dengan etnomatematika yang diyakini dapat menambah kualitas pemahaman siswa, dan juga bisa digunakan sebagai salah satu pilihan lain dalam pembelajaran yang dapat diberikan dan diterapkan kepada siswa agar dapat melatih pola pikir serta cara kerja secara ilmiah dalam membangun pemahaman konsep yang terintegrasi budaya lokal dan lebih mudah dimengerti karena berkenaan langsung dengan lingkungan asal mereka, serta untuk menambah pengetahuan tentang ciri khas kelokalan yang ada didaerah Jember. Oleh karena itu, penelitian ini dilakukan untuk menguraikan kualitas bahan ajar yang sedang dikembangkan, berupa Lembar Kerja Siswa (LKS) berbasis etnomatematika pada materi Trigonometri di masjid Cheng-Ho di Jember.

Copyright (C) 2021

Buana Matematika :

Jurnal Ilmiah Matematika dan Pendidikan Matematika 


\section{Metode}

Penelitian pengembangan LKS materi trigonometri berbasis etnomatematika pada masjid Cheng-Ho di Jember termasuk penelitian pengembangan atau Research and Development (R\&D) dan pada penelitian ini menggunakan model pengembangan ADDIE. ADDIE dipilih karena lebih mudah digunakan dan dipahami daripada pengembangan model yang lain, serta tahapantahapan pada model ini sama dengan tahapan yang sudah dilakukan oleh peneliti dalam mengembangkan LKS berbasis etnomatematika. Produk yang dikembangakan oleh peneliti yaitu berupa LKS materi trigonometri yang diintegrasikan dengan etnomatematika pada masjid Cheng-Ho di Jember untuk siswa kelas $X$ dengan berdasarkan pada model pengembangan yang telah dipilih oleh peneliti, yang mencakup tahap analisis, perancangan, pengembangan, implementasi, serta evaluasi.

Terdapat dua jenis data yang dipakai oleh peneliti yaitu data kualitatif yang didapatkan berdasarkan saran dari para validator dan data kuantitatif yang didapatkan berdasarkan perolehan instrumen kelayakan, angket respon guru dan siswa, serta tes hasil belajar siswa yang kemudian dianalisis dan diubah bentuknya menjadi data kualitatif. Dalam mengumpulkan data-data tersebut, peneliti menggunakan instrumen-instrumen yang mencakup lembar validasi (terdiri dari lembar validasi materi, desain, serta ahli media) yang tujuannya untuk mengatahui apakah LKS yang dikembangkan sudah layak atau belum jika dilihat dari segi kevalidan; angket respon guru dan siswa yang tujuannya untuk mengatahui apakah LKS yang dikembangkan sudah layak atau belum jika ditinjau dari aspek kepraktisan; dan tes hasil belajar siswa yang tujuannya untuk mengatahui apakah LKS yang telah dibuat sudah layak atau belum jika ditinjau dari aspek keefektivan.

Penelitian pengembangan LKS materi trigonometri berbasis etnomatematika pada masjid Cheng-Ho di Jember diberikan pada siswa kelas X. Subjek dalam penelitian ini menggunakan sampel uji coba terbatas yang diujikan kepada 6 orang siswa kelas $\mathrm{X}$.

Pada tahap analisis, terdapat dua kegiatan yang dilakukan oleh peneliti, yaitu : 1. Analisis kebutuhan, dilakukan dengan cara menentukan jenis bahan ajar yang diperlukan; 2. Analisis kurikulum, yaitu peneliti menentukan dan mengkaji KI dan KD yang harus dikuasai oleh siswa pada materi trigonometri sesuai dengan kurikulum yang berlaku. Pada tahap perancangan, terdapat dua kegiatan yang dilakukan, yaitu kegiatan merancang insrumen kelayakan 
LKS dan penyusunan LKS. LKS dibuat dengan memuat 5 komponen yakni judul, kompetensi pencapaian, petunjuk belajar dan tujuan pembelajaran, informasi pendukung, contoh soal dan tugas. Instrumen kelayakan LKS yang dibuat berupa lembar validasi yang mencakup lembar validasi materi, desain, serta ahli materi, angket respon guru dan siswa, serta tes hasil belajar siswa.

Pada tahap pengembangan, hal yang dilakukan oleh peneliti yaitu mengembangkan LKS sesuai dengan kerangka yang telah dibuat pada tahap perancangan. LKS yang telah dibuat diberikan kepada para ahli (validator) untuk divalidasi dengan menggunakan instrumen kelayakan berupa lembar validasi. Penilaian kevalidan LKS dapat ditinjau berdasarkan hasil penilaian validator pada lembar validasi untuk menentukan apakah LKS sudah layak atau belum untuk diuji cobakan pada kelompok kecil (terbatas). Pada tahap ini, lembar validasi dianalisis. Instrumen yang digunakan untuk manganalisis kevalidan yaitu menggunakan lembar validasi materi, desain, dan ahli media. Peneliti mneganalisis lembar validasi yang sudah diberi penilaian oleh validator berdasarkan langkah-langkah berikut:

1. Lembar validasi berisi tentang pertanyaan-pertayaan yang diukur dengan skala Likert. Seperti tabel berikut:

Tabel 1. Kategori Skala Likert

\begin{tabular}{cc}
\hline Pernyataan & Skor \\
\hline Sangat setuju (SS) & 5 \\
Setuju (S) & 4 \\
Ragu-ragu (R) & 3 \\
Tidak setuju (TS) & 2 \\
Sangat tidak setuju (STS) & 1 \\
\hline
\end{tabular}

2. Lembar validasi yang telah diberi nilai oleh para ahli (validator), kemudian dihitung presentasenya menggunakan rata-rata dari jumlah skor yang diperoleh dari setiap aspek terhadap pertanyaan yang ada. Perhitungan lembar validasi dipisah antara lembar validasi materi, desain, dan ahli materi. Perhitungannya menggunakan rumus sebagai berikut.

$$
\begin{aligned}
& P=\frac{\sum(\text { jawaban } \times \text { bobot tiap pilihan })}{n \times \text { bobot terting } i} \times 100 \% \\
& \text { Dimana } \quad: \text { presentase } \\
& P \quad
\end{aligned}
$$




$$
\sum_{n} \quad: \text { jumlah }
$$

3. Kemudian rata-rata skor yang didapatkan dikonversi ke dalam bentuk data kualitatif berdasarkan pedoman tafsiran menurut Arikunto, yaitu dapat dilihat pada tabel berikut.

Tabel 2. Tafsiran

\begin{tabular}{cc}
\hline Presentase & Krieria \\
\hline $80,1 \%-100 \%$ & Sangat tinggi \\
$60,1 \%-80 \%$ & Tinggi \\
$40,1 \%-60 \%$ & Sedang \\
$20,1 \%-40 \%$ & Rendah \\
$0,0 \%-20 \%$ & Sangat rendah \\
\hline
\end{tabular}

Pada lembar validasi, Skor tertinggi dan terendahnya berturut-turut adalah 5 dan 1. Berdasarkan aspek kevalidan, LKS dapat dikatakan layak jika hasil perhitungan lembar validasi berada pada kategori tinggi atau sangat tinggi. Penentuan kategori dapat dintinjau menggunakan tebel tafsiran. Kategori tinggi dapat dikatakan valid. Sedangkan kategori sangat tinggi dapat dikatakan sangat valid.

Tahap implementasi, hal yang dilakukan oleh peneliti pada tahap ini, yaitu mengujicobakan LKS yang telah dibuat kepada kelompok terbatas (kecil). Tujuan dari tahap ini yaitu untuk mengetahui tingkat keefektivan yang mengacu pada perolehan hasil tes belajar siswa dan kepraktisan yang mangacu pada lembar angket respon guru dan siswa. Kepraktisan dan keefektivan digunakan untuk mengetahui kalayakan LKS.

Tahap selanjutnya yaitu evaluasi. Hal yang dilakukan oleh peneliti pada tahap ini, yaitu menganalisis hasil angket guru dan siswa serta perolehan nilai siswa pada latihan yang ada pada LKS (hasil tes belajar siswa) yang tujuannya agar dapat merevisi LKS atau tidak perlu merevisinya yang mengacu pada saransaran yang terdapat pada lembar angket respon guru dan siswa yang telah dibagikan. Nilai yang terdapat pada lembar pernyataan serta latihan siswa kemudian dianalisis sesuai pedoman berikut:

1. Data yang dibutuhkan untuk menganalisis kepraktisan diperoleh berdasarkan hasil respon dari siswa dan guru setelah belajar dengan

Copyright $@ 2021$

Buana Matematika :

Jurnal Ilmiah Matematika dan Pendidikan Matematika 
menggunakan LKS yang dikemas dalam bentuk angket. Pada lembar angket respon guru dan siswa digunakan skala Likert dengan metode cheklist untuk menjawab pertanyaan-pertanyaan yang ada. Skala Likert sering diterapkan dengan tujuan untuk mengukur persepsi, sikap, dan pendapat seseorang.

Pengelolaan jumlah skor responden serta skor angket dilakukan dengan pedoman berikut:

a. Skor untuk pertanyaan dengan jawaban sangat setuju, skor = $4 \times$ jumlah jawaban responden

b. Skor untuk pertanyaan dengan jawaban setuju, skor $=3 \times$ jumlah jawaban responden

c. Skor untuk pertanyaan dengan jawaban tidak setuju, skor = $2 \times$ jumlah jawaban responden

d. Skor untuk pertanyaan dengan jawaban sangat tidak setuju, skor = $1 \times$ jumlah jawaban responden

2. Hasil nilai dari pernyataan-pernyataan yang ada kemudian dihitung presentasenya dengan mencari rata-rata jumlah skor pada setiap aspek yang diambil dari hasil pengelolaan jawaban setiap pertanyaan. Perhitungan yang dilakukan menggunakan rumus berikut:

$\% X_{\text {in }}=\frac{\sum s}{S_{\text {maks }}} \times 100 \%$

Dimana

$\% X_{\text {in }} \quad$ : Presentase skor jawaban dari semua pernyataan yang terdapat pada angket

$\sum s \quad$ : Jumlah seluruh nilai jawaban

$S_{\text {maks }} \quad$ : Nilai maksimum yang diharapkan

3. Rata-rata skor yang telah didapatkan kemudian dikonversi kedalam bentuk data kualitatif berdasarkan pedoman tafsiran yang dikemukakan oleh Arikunto.

Tabel 3. Tafsiran

\begin{tabular}{cc}
\hline Presentase & Krieria \\
$80,1 \%-100 \%$ & Sangat tinggi \\
$60,1 \%-80 \%$ & Tinggi \\
$40,1 \%-60 \%$ & Sedang \\
$20,1 \%-40 \%$ & Rendah \\
\hline
\end{tabular}

Copyright $@ 2021$

Buana Matematika :

Jurnal Ilmiah Matematika dan Pendidikan Matematika 


\begin{tabular}{ll}
\hline $0,0 \%-20 \%$ & Sangat rendah \\
\hline
\end{tabular}

Skor tertinggi dan terendah yang terdapat pada angket respon guru dan siswa berturut-turut ialah 4 dan 1. LKS dikatakan parktis, jika perolehan hasil perhitungan dan analisis pada lembar angket guru dan siswa sudah terdapat pada kategori tinggi atau sangat tinggi. Penentukan kategori dapat ditentukan menggunakan tabel tafsiran yang sudah dibuat. Kategori tinggi dapat dikatakan praktis, sedangkan kategori sangat tinggi dapat dikatakan sangat praktis.

Langkah selanjutnya ialah menentukan keefektivan dari LKS yang sedang dikembangkan. Instrumen yang dipakai yaitu tes perolehan belajar siswa yang kemudian di analisis dan dihitung menggunakan cara-cara berikut.

1. Perolehan hasil dari tes hasil belajar siswa kemudian dihitung skor perolehannya, menggunakan rumus berikut:

Skor $=\frac{\text { jumlah jawaban benar }}{\text { banyak soal }} \times 100$

2. Skor yang didapat kemudian ditentukan apakah sudah tuntas atau belum menggunakan ketentuan yang sudah ditetapkan yaitu $\geq 65$. Dengan artian bahwa siswa dapat dinyatakan tuntas jika skor perolehannya $\geq 65$. Peneliti menetapkan siswa dapat dinyatakan tuntas jika perolehan skornya $\geq 65$, dikarenakan 65 merupakan nilai KKM atau batasan minimal nilai yang perlu diperoleh siswa untuk dapat dinyatakan tuntas.

3. Selanjutnya Lembar Kerja Siswa (LKS) dapat dikatakan efektif apabila memenuhi dua kriteria, yakni LKS tuntas secara individual dan klasikal. Ketuntasan individual diperoleh, apabila semua siswa skor perolehannya $\geq 65$. Ketuntasan klasikal diperoleh, apabila rata-rata siswa yang tuntas yaitu $\geq 85 \%$.

\section{Hasil dan Pembahasan}

Menurut Trianto (2015)menyatakan bahwa didalam psikologi pendidikan, salah satu konsep yang terpenting ialah guru selain mentransferkan ilmunya kepada siswa, guru juga harus meningkatkan pengetahuan yang ada di dalam dirinya. Menurut Oktavia dan Zahra (2016) menyatakan bahwa guru matematika dianjurkan untuk merancang Lembar Kerja Siswa (LKS) sebagai bahan ajar agar dapat membimbing siswanya dalam membangun sendiri rancangan pengetahuan dalam dirinya, yang ingin guru sampaikan melalui materi yang sudah tersusun rapi serta sistematis didalam sebuah Lembar Kerja Siswa (LKS), dengan kata lain penguatan konsep dalam pembelajaran 
sangat diperlukan untuk menambah kualitas pemikiran serta pemahan konsep pada diri siswa (Subakri \& Annizar, 2021).

LKS yang dikembangkan oleh peneliti merupakan LKS yang berbasis etnomatematika yang efektif dalam menambah kualitas pemahan konsep terhadap siswa, hal tersebut selaras dalam penelitian yang telah dilakukan oleh Peni, dkk (2019) dan Annizar (2015) bahwa ternyata terdapat perbedaan pada tingkat pemahaman antara siswa yang diberi materi pembelajaran terintegrasi dengan etnomatematika dengan siswa yang yang tidak diberi materi pembelajaran yang diintegrasikan dengan etnomatematika.

Pengembangan LKS diawali dengan tahap analisis, dimana pada tahap analisis terdapat 2 kegiatan, yaitu : 1. Analisis kebutuhan, peneliti menggunakan bahan ajar LKS materi trigonometri berbasis etnomatematika pada masjid Cheng-Ho di Jember, agar siswa dapat memahami konsep trigonometri yang diintegrasikan melalui etnomatematika; 2. Analisis kurikulum, peneliti menggunakan KI 3 dan KD 3.7 dan 4.7 pada kelas X sesuai dengan kurikulum yang berlaku. Kemudian dilanjutkan tahap desain (perancangan) terdiri dari 2 kegiatan, membuat LKS yang memuat materi, permasalahan, latihan soal, serta petunjuk belajar dan instrumen kelayakan yang memuat lembar validasi materi, desain, serta ahli media. Peneliti pada tahap ini mendesain LKS dengan ukuran huruf yang tepat, warna yang menarik, dan terdapat ilustrasi (gambar) yang membuat siswa mudah dalam memahami dan mengerti materi sehingga siswa termotivasi dan semangat dalam membaca dan memahami serta mengerti materi yang tercantum dalam LKS. Hal ini selaras dengan pernyataan Wibowo dalam Hersandi, Mahardika dan Nuriman (2017) bahwa grafika adalah bagian fisik buku yang meliputi jenis kertas, warna, ukuran, ilustrasi, cetakan, ukuran huruf yang terdapat pada bahan dan dikemas secara baik agar siswa tertarik dan termotivasi untuk membacanya. Hal tersebut selaras dalam penelitian yang telah dilakukan oleh Astuti dan Sari (2017) bahwa LKS yang didesain dengan gambar dan warna yang menarik dapat membuat siswa termotivasi dan tertarik untuk membuka dan membaca LKS serta akan disimpan dengan baik oleh siswa. Berikut cuplikan gambar pengaplikasian trigonometri pada masjid Cheng-Ho di Jember.

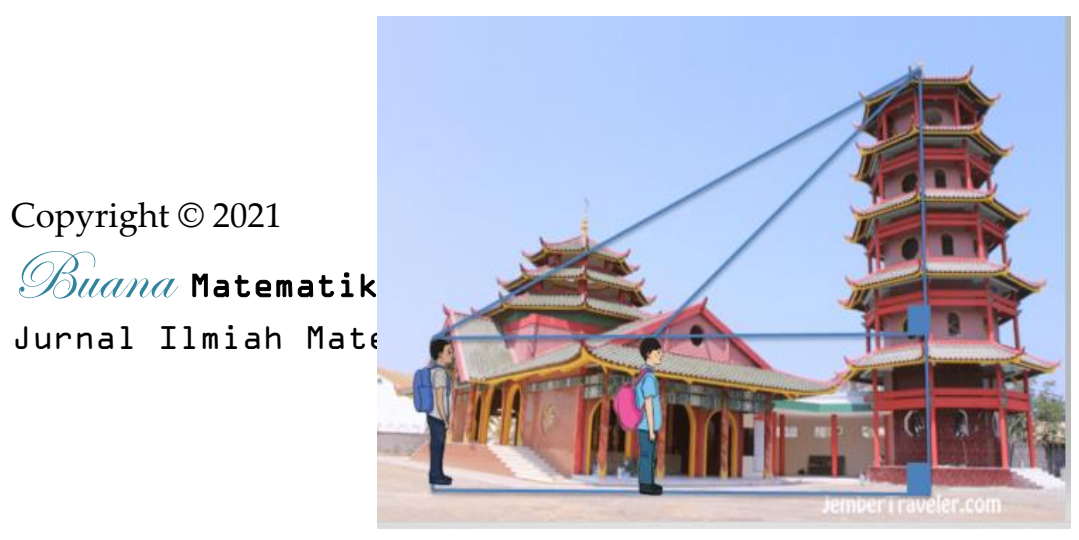


Gambar 1. Penerapan trigonometri pada masjid Cheng-Ho di Jember

Kemudian dilanjutkan pada tahap development (pengembangan). LKS yang sudah dikembangkan diberikan kepada para ahli (validator) untuk divalidasi menggunakan instrumen kelayakan yang telah dibuat yaitu lembar validasi LKS. Perhitungan tingkat kevalidan LKS dilakukan berdasarkan perolehan dari lembar validasi, yang dapat dilihat pada tabel berikut.

Tabel 4. Perolehan Perolehan Lembar Validasi

\begin{tabular}{lllllll}
\hline Validator & SS (5) & S (4) & R (3) & TS (2) & STS (1) & Jumlah \\
\hline Ahli materi & 10 & 20 & 3 & & 33 \\
Ahli media & 20 & 12 & 6 & & 38 \\
Ahli desain & 20 & 24 & 3 & 2 & 49 \\
\hline
\end{tabular}

Berdasarkan tabel 4 dan dan hasil perhitungan lembar validasi, diperoleh skor sebesar $82,5 \%$ untuk hasil validator materi dan termasuk kedalam kategori sangat tinggi. Saran yang didapat dari hasil validasi yaitu untuk memperbaiki contoh permasalah 2. Untuk hasil validator media diperoleh skor sebesar $84,4 \%$ dan termasuk kategori sangat tinggi. Saran yang diberikan oleh validator media yaitu bahwa "LKS ini dapat digunakan dengan sedikit revisi". Untuk hasil validator desain diperoleh skor sebesar $81,67 \%$ dan termasuk kategori sanngat tinggi. Dan lembar validasi dapat dikatakan valid jika hasil kategori yang didapatkan minimal di kategori tinggi dan sangat valid jika hasil kategori yang didapatkan ada di kategori sangat tinggi. Berdasarkan paparan di atas maka, materi pada LKS sudah valid, media dan desain LKS sudah sangat valid.

Dari saran validator pada lembar validasi, peneliti merevisi LKS sesuai dengan hasil validasi. Kemudian LKS yang sudah direvisi kemudian dilanjutkan pada tahap implementasi, pada tahap ini LKS diujikan pada kelompok terbatas (kecil) yang diberikan pada 6 siswa yang mengerjakan latihan pada LKS dan mengisi lembar angket respon siswa dan 1 guru yang menilai LKS serta mengisi lembar angket respon guru. Kemudian dilanjutkan

Copyright $@ 2021$

Buana Matematika :

Jurnal Ilmiah Matematika dan Pendidikan Matematika 
pada tahap kelima atau terakhir, yaitu tahap evaluasi. Evaluasi yang dilakukan oleh peneliti yaitu menganalisis hasil angket respon guru dan siswa serta perolehan nilai siswa setelah mengerjakan latihan pada LKS (hasil tes belajar siswa).Analisis terhadap perolehan nilai siswa bertujuan untuk mengetahui apakah LKS layak dan bermanfaat untuk diimplementasikan pada kegiatan belajar mengajar. Hal ini selaras dengan pernyataan Nasution dalam Fannie dan Rohati (2014) bahwa hasil belajar yaitu perolehan (hasil) atas interaksi kegiatan belajar mengajar yang biasanya ditunjukkan dari nilai tes siswa yang diberikan guru.

Perhitungan tingkat keefektivan LKS dilakukan berdasarkan hasil dari hasil tes siswa, sebagai berikut. Tes soal terdiri dari 3 butir soal dan berupa uraian. Adapun nilai ketuntasan siswa yaitu harus $\geq 65$

Tabel 5. Hasil Nilai Perolehean Siswa

\begin{tabular}{cc}
\hline Responden & Skor yang diperoleh \\
\hline 1 & 75 \\
2 & 100 \\
3 & 83 \\
4 & 83 \\
5 & 67 \\
6 & 83 \\
\hline
\end{tabular}

Tabel 6. Data Ketuntasan

\begin{tabular}{ccccc}
\hline No & Nilai & Kategori & Frekuensi & Presentase (\%) \\
\hline 1 & $0-64$ & Tidak tuntas & 0 & $0 \%$ \\
2 & $65-100$ & Tuntas & 6 & $100 \%$ \\
& Jumlah & & 6 & $100 \%$ \\
\hline
\end{tabular}

Berdasarkan tabel 5. Hasil nilai perolehan siswa, semua siswa yang diuji cobakan sebanyak 6 siswa mempunyai nilai yang lebih dari 65. Dan berdasarkan ketuntasan, keenam siswa dinyatakan tuntas. Sehingga berdasarkan ketuntasan individual, semua siswa tuntas. Dan berdasarkan tabel 6, data ketuntasan. Diperoleh bahwa rata-rata siswa yang tuntas yaitu $100 \%$. Sehingga dapat dinyatakan secara ketuntasan kelompok bahwa LKS ini tuntas berdasarkan ketuntasan kelompok, karena rata-rata ketuntasan yang diperoleh sudah lebih dari 85\%. Sehingga berdasarkan uraian diatas LKS Copyright (C) 2021

Buana Matematika :

Jurnal Ilmiah Matematika dan Pendidikan Matematika 
materi trigonometri berbasis etnomatematika pada masjid Cheng-Ho di Jember dapat dikatan efektiv. Dan berada pada kategori sangat baik.

Berdasarkan paparan di atas, keefektivan LKS materi triginometri berbasis etnomatematika pada masjid Cheng-Ho di Jember dibuktikan atas tabel 5 dan 6 didapatkan bahwa sebanyak 6 siswa dari 6 siswa mampu memahami materi tentang trigonometri yang ada pada LKS dengan masksimal. Hal ini selaras dengan penjelasan yang dijelaskan oleh Trianto dalam Norsanty dan Chairani (2016) bahwa di dalam LKS harus terdapat kumpulan-kumpulan kegiatan yang harus dikerjakan siswa, yang tujuannya untuk mengoptimalkan indikator yang harus dicapai siswa mengenai pencapaian hasil belajar terkait dengan pemhaman konsep dasar pengetahuan. LKS ini juga dikatakan efektif, karena dapat membuat siswa membangun sendiri pengethuannya tentang rumus penentuan nilai dari sin, cos, tan, sec, csc. Hal tersebut dapat diperoleh siswa melalui penyelesaian permasalahan-permasalahan yang ada di LKS. Dimana, pada permasalah yang terdapat pada LKS, siswa dituntun bisa memecahkan masalah yang ada. Hal ini selaras dengan pernyataan Bruner dalam Norsanty dan Chairani (2016) maupun Annizar, dkk (2021) yang menyatakan bahwa siswa dapat membangun dasar pengetahuannya sendiri terhadap suatu materi dengan cara guru yang membimbing dan menuntun siswa bukan hanya diajari melalui memorisasi atau hafalan.

Perhitungan tingkat kepraktisan LKS dilakukan berdasarkan hasil dari hasil lembar angket respon guru dan siswa, yang terdapat pada tabel berikut.

Tabel 7. Hasil respon siswa

\begin{tabular}{llllll}
\hline Responden & SS & S & TS & STS & Jumlah \\
\hline 1 & 68 & 6 & - & 1 & 75 \\
2 & 72 & 3 & 2 & - & 77 \\
3 & 72 & 6 & - & - & 78 \\
4 & 12 & 60 & - & - & 72 \\
5 & 32 & 36 & - & - & 68 \\
6 & 16 & 36 & 8 & - & 60 \\
Jumlah & & & & & 430 \\
\hline
\end{tabular}

Tabel 8. Hasil respon guru

\begin{tabular}{llllll}
\hline Responden & SS & S & TS & STS & Jumlah \\
\hline 1 & 32 & 48 & 6 & - & 86 \\
\hline
\end{tabular}

Copyright (C) 2021

Buana Matematika :

Jurnal Ilmiah Matematika dan Pendidikan Matematika 
Berdasarkan tabel 7 dan dan hasil perhitungan lembar angket siswa, diperoleh skor sebesar $89,6 \%$ dan termasuk kedalam kategori sangat tinggi. Berdasarkan tabel 8 dan dan hasil perhitungan lembar angket guru, diperoleh skor sebesar 79,63\% dan termasuk kedalam kategori tinggi. karena LKS dapat dikatakan praktis jika dalam kategori tinggi dan sangat praktis jika dalam kategori sangat tinggi. Maka berdsarakan paparan ditas, dapat dikatakan bahwa LKS materi triginometri berbasis etnomatematika pada masjid Cheng-Ho di Jember termasuk praktis.

Berdasarkan paparan di atas, LKS materi triginometri berbasis etnomatematika pada masjid Cheng-Ho di Jember praktis dan dapat diberikan kepada siswa untuk dipelajarai dan digunakan, sehinggaaktivitas belajar mengajar bisa terlaksana dengan baik dan kreatif, hal ini selaras dengan teori yang dikemukakan oleh Burner dalam Norsanty dan Chairani (2016) maupun Annizar dan Arifin (2021) bahwa kegiatan proses pembelajaran akan berjalan kreatif dan baik bila guru memberikan kepada siswa cara untuk menentukan petunjuk sendiri baik menggunakan definisi, teori, konsep dan lain-lain. Karena LKS materi triginometri berbasis etnomatematika pada masjid ChengHo di Jember dikatakan praktis, sehingga LKS ini dapat menuntun siswa dalam menemukan dan mencari sendiri bagian sudut dan rumus untuk setiap fungsi trigonometri, seperti nilai sin, $\cos$, tan, sec, dan csc.

Penggunaan LKS yang diintegrasikan dengan majid Cheng-Ho di Jember merupakan hal yang baru bagi 6 siswa yang mengikuti uji coba LKS, sehingga membuat siswa semangat dan terdorong untuk mendalami materi selain trigonometri yang berhubungan dengan budaya yang ada. Hal ini selaras dalam penelitian yang telah dilakukan oleh Ricardo (2016) bahwa etnomatematika dapat memberikan lingkungan belajar yang memberikan motivasi positif yang menyenangkan, sehingga dapat menghilangkan konsep yang mengatakan bahwa matematika itu merupakan momok dan menakutkan.

\section{Simpulan}

Simpulan yang diambil oleh peneliti berlandaskan pada hasil dan pembahasan yang diperoleh, yaitu pengembangan LKS materi triginometri berbasis etnomatematika pada masjid Cheng-Ho di Jember pada siswa kelas $X$ jenjang SMA dikembangkan oleh peneliti sesuai dengan tahapan yang ada pada model pengembangan ADDIE yang memuat lima tahap. Dan LKS Copyright $\odot 2021$

Buana Matematika :

Jurnal Ilmiah Matematika dan Pendidikan Matematika 
materi triginometri berbasis etnomatematika pada masjid Cheng-Ho di Jember dapat ditinjau kelayakannya dari segi kevalidan, keefektivan, serta kepraktisan dengan meninjau dari: Hasil validasi oleh validator yang terdapat pada kategori sangat tinggi atau sangat valid baik pada lembar validasi materi, desain, dan ahli media; perolehan lembar angket respon guru terdapat pada kategori tinggi atau praktis. Sedangkan perolehan lembar angket respon siswa terdapat pada kategori sangat tinggi atau sanagt praktis; perolehan tes belajar siswa terdapat pada kategori sangat baik atau efektif.

\section{Ucapan Terima Kasih}

Ucapan terimakasih kepada Rektor, Dekan, serta Ketua Program Prodi Tadris Matematika IAIN Jember serta semua pihak yang telah banyak memberikan bantuan dalam penyelesaian penelitian ini.

\section{Daftar Pustaka}

Aini, A. N., Mukhlis, M., Annizar, A. M., Jakaria, M. H. D., \& Septiadi, D. D. (2020, February). Creative thinking level of visual-spatial students on geometry HOTS problems. In Journal of Physics: Conference Series (Vol. 1465, No. 1, p. 012054). IOP Publishing. doi:10.1088/17426596/1465/1/012054

Annizar, Anas Ma'ruf. (2015). Analisis Kemampuan Pemecahan Masalah Soal PISA Menggunakan Model IDEAL pada Siswa usia 15 Tahun di SMA Nuris Jember. Skripsi. Jember: Universitas Jember

Annizar, Anas Ma'ruf, and Miftah Arifin. (2021). Perbedaan Prestasi Belajar Mahasiswa Ditinjau dari Jalur Seleksi Masuk Perguruan Tinggi." SAP (Susunan Artikel Pendidikan) 5.3.

Annizar, A. M., Lestari, A. C., Dalimarta, S., \& Wulandari, Y. N. (2021). The process of student analytical thinking in understanding and applying lattice method to solve mathematical problem." Journal of Physics: Conference Series. 1836 (1). IOP Publishing. doi:10.1088/17426596/1836/1/012047

Annizar, A. M., Jakaria, M. H. D., Mukhlis, M., \& Apriyono, F. (2020, February). Problem solving analysis of rational inequality based on IDEAL model. In Journal of Physics: Conference Series (Vol. 1465, No. 1, p. 012033). IOP Publishing. doi: 10.1088/1742-6596/1465/1/012033

Annizar, A. M. R., Lestari, A. C., Sofiah, S., Khairunnisa, G. F., \& Maulyda, M. A. (2020). Proses berpikir inkuiri dalam menyelesaikan masalah higher order thinking skills (hots) ditinjau dari tingkat kognitif. AKSIOMA: 
Jurnal Program Studi Pendidikan Matematika, 9(4), 1192-1204. https://doi.org/10.24127/ajpm.v9i4.3113

Annizar, A. M. R., Sisworo, S., \& Sudirman, S. (2018). Pemecahan Masalah menggunakan Model IDEAL pada Siswa Kelas X Berkategori FastAccurate. Jurnal Pendidikan: Teori, Penelitian, dan Pengembangan, 3(5), 634-640.

Annizar, A. M. R., \& Zahro, F. S. (2020). Proses Berpikir Metafora dalam Menyelesaikan Masalah Matematis Soal HOTS Berdasarkan Kemampuan Kognitif Siswa. Jurnal Tadris Matematika, 3(2), 117-130. DOI: http://dx.doi.org/10.21274/jtm.2020.3.2.117-130

Andari, T., \& Komsiatun, E. (2018). Pengembangan LKS berbasis pendekatan realistic mathematics education untuk meningkatkan kemampuan matematis siswa. AKSIOMA: Jurnal Program Studi Pendidikan Matematika, 7(1), 155-160.

Arifin, Z. A. I., \& Sepriyani, D. N. A. (2019). Pengembangan Lks Matematika dengan Pendekatan Saintifik Pokok Bahasan Polinomial untuk Sma Kelas XI. Prima: Jurnal Pendidikan Matematika, 3(1), 9-15.

Astuti, A., \& Sari, N. (2017). Pengembangan Lembar Kerja Siswa (LKS) pada Mata Pelajaran Matematika Siswa Kelas X SMA. Jurnal Cendekia: Jurnal Pendidikan Matematika, 1(2), 13-24.

Astuti, Y., \& Setiawan, B. (2013). Pengembangan lembar kerja siswa (LKS) berbasis pendekatan inkuiri terbimbing dalam pembelajaran kooperatif pada materi kalor. Jurnal Pendidikan IPA Indonesia, 2(1).

Fannie, R. D., \& Rohati, R. (2014). Pengembangan lembar kerja siswa (LKS) berbasis POE (predict, observe, explain) pada materi program linear kelas XII SMA. Sainmatika: Jurnal Sains dan Matematika Universitas Jambi, 8(1), 221053.

Febriani, P., Widada, W., \& Herawaty, D. (2019). Pengaruh pembelajaran matematika realistik berbasis etnomatematika terhadap kemampuan pemahaman konsep matematika siswa SMA Kota Bengkulu. Jurnal Pendidikan Matematika Raflesia, 4(2), 120-135.

Hasanah, S. I., Hafsi, A. R., \& Zayyadi, M. (2019). Pengembangan Lembar Kerja Siswa Berbasis Etnomatematika Dalam Membangun Pemahaman Konsep Siswa. Jurnal Pendidikan Matematika dan IPA, 10(2), 183-191.

Hersandi, M., Mahardika, I. K., \& Nuriman, N. (2017). Pengembangan Bahan Ajar Lembar Kerja Siswa (LKS) dalam Bentuk Brosur untuk Pembelajaran IPA di SMP ditinjau dari Aspek Kegrafikaannya. Jurnal Pembelajaran dan Pendidikan Sains, 2(1), 57-64.

Copyright $@ 2021$

Buana Matematika:

Jurnal Ilmiah Matematika dan Pendidikan Matematika 
Khairunnisa, G. F., Maulyda, M. A., Annizar, A. M. R., Hijriani, L., \& Khair, M. S. D. (2020). Mathematics Communication: Translation of Elementary Students' Idea. NUMERICAL: Jurnal Matematika Dan Pendidikan Matematika, 77-86. doi: 10.25217/numerical.v4i2.781

Khalimah, N., Farin, K. I., Nikmah, M., Ni'mah, K., \& Jatmiko, J. (2017). Budaya kediri dalam pembelajaran matematika (pengembangan lembar kegiatan siswa (LKS) berbasis etnomatematika melalui pendekatan saintifik). JIPMat, 2(1).

Lestari, A. C., \& Annizar, A. M. R. (2020). Proses Berpikir Kritis Siswa dalam Menyelesaikan Masalah PISA ditinjau dari Kemampuan Berpikir Komputasi. Jurnal Kiprah, 8(1), 46-55. https://doi.org/10.24127/ajpm.v9i4.3113

Maulyda, M. A., Hidayati, V. R., Apsari, R. A., Firda, G., \& Khairunnisa, A. M. R. A. (2020). How Students Find Patterns?: Mathematical Representations in the Laws of Proximity, Closure, and Similarity. Jurnal Cakrawala Pendidikan, 39(2), 1-17.

Muafiqi, S., \& Jailani. (2014). Pengembangan Bahan Ajar Matematika yang Berorientasi pada Karakter dan Higher Order Thinking Skill(HOTS). PYTHAGORAS:Jurnal Pendidikan Matematika, 9 (1), 45-59.

Nizaruddin, N., \& Murtianto, Y. H. (2017). Pengembangan Video Pembelajaran Matematika Berbantuan Macromedia Flash 8 dengan Pendekatan Kontekstual Pada Materi Program Linier Kelas XI. AKSIOMA: Jurnal Matematika dan Pendidikan Matematika, 8(2), 9-18.

Norsanty, U. O., \& Chairani, Z. (2016). Pengembangan lembar kerja siswa (LKS) materi lingkaran berbasis pembelajaran guided discovery untuk siswa SMP kelas VIII. Math Didactic: Jurnal Pendidikan Matematika, 2(1), 12-23.

Nurafni, A., Pujiastuti, H., \& Mutaqin, A. (2020). Pengembangan Bahan Ajar Trigonometri Berbasis Kearifan Lokal. Journal of Medives:Journal of Mathematics Education IKIP Veteran Semarang, 4 (1), 71-80.

Oktarina, A., Luthfiana, M., \& Refianti, R. (2019). Pengembangan Lembar Kerja Siswa (LKS) Etnomatematika Berbasis Penemuan Terbimbing pada Materi Bangun Ruang Sisi Datar. Jurnal Pendidikan Matematika: Judika Education, 2(2), 91-101.

Putra, R. W. Y., \& Anggraini, R. (2016). Pengembangan Bahan Ajar Materi Trigonometri Berbantuan Software iMindMap pada Siswa SMA. AlJabar: Jurnal Pendidikan Matematika, 7(1), 39-47. 
Richardo, R. (2017). Peran ethnomatematika dalam penerapan pembelajaran matematika pada kurikulum 2013. LITERASI (Jurnal Ilmu Pendidikan), 7(2), 118-125.

Subakri \& Annizar, A. M. (2021). The effects of covid-19 in learning: effective and efficient online learning models of mathematical statistics and real analysis from the students' perspective. Journal of Physics: Conference Series. 1836(1). doi:10.1088/1742-6596/1836/1/012048

\section{Riwayat Hidup Penulis}

\section{Anas Ma'ruf Annizar}

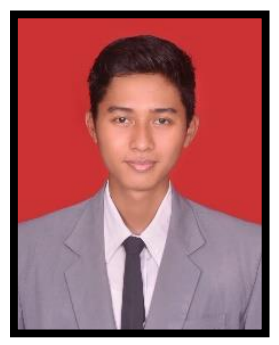

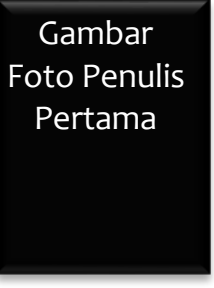

Scopus.
Lahir di Jember, 16 Februari 1994. Dosen di Tadris Matematika FTIK IAIN Jember. Studi S1 Pendidikan Matematika Universitas Jember, Jember, lulus tahun (2016); S2 Pendidikan Matematika Universitas Negeri Malang, Malang, lulus tahun (2018). Informasi publikasi terbaik yang pernah dilakukan berupa penulis artikel yang diterbitkan di jurnal terindek

\section{Annisaul Kholida}

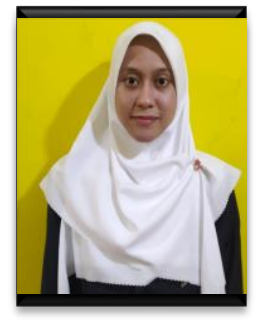

Lahir di Jember, 20 Februari 2000. Mahasiswa yang sedang menempuh pendidikan S1, Prodi Tadris Matematika di IAIN Jember.

\section{Atika Alfitria}

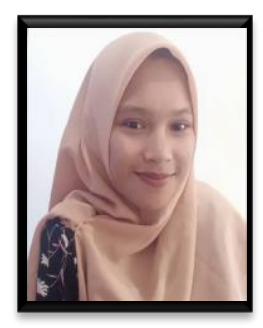

Lahir di Jember, 18 Maret 2000. Mahasiswa yang sedang menempuh pendidikan S1, Prodi Tadris Matematika di IAIN Jember

Copyright $(02021$

Buana Matematika :

Jurnal Ilmiah Matematika dan Pendidikan Matematika 


\section{Abdullah Subhi Yusuf}

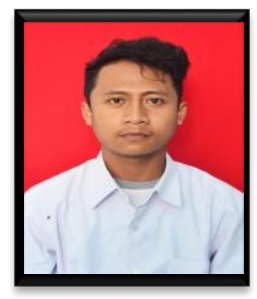

Lahir di Jember, 16 Januari 2000. Mahasiswa yang sedang menempuh pendidikan S1, Prodi Tadris Matematika di IAIN Jember. 
Jurnal Ilmiah Matematika dan Pendidikan Matematika

Vol. 11 No. 1 (2021)

Copyright (C) 2021

Buana Matematika :

Jurnal Ilmiah Matematika dan Pendidikan Matematika 